\title{
Balancing the local and global: A review of teaching and learning literature from Colombia
}

\author{
Alison Reedy ${ }^{1,2}$, María Lucía Guerrero Farías ${ }^{1}$ \\ ${ }^{1}$ Centro de Eseñanza y Aprendizaje, Facultad de Educación, Universidad de los Andes, \\ Colombia, ${ }^{2}$ Centre for Learning and Teaching, Charles Darwin University, Australia.
}

\begin{abstract}
This paper presents a systematic review of the extent and nature of teaching and learning research in Colombia. The study identified that teaching and learning research is growing but is unevenly spread amongst a small number of Colombian private and public universities. The quantity of learning and teaching research emerging from a small number of institutions is linked to the presence of education development centres that support the research and dissemination of teaching innovation. The dominance of research related to technology innovation reflects the purpose of these centres. The teaching and learning research literature emerging from these universities reflects global educational themes but contains little of the issues and challenges related to diversity, inequality, and other social, political and economic realities that situates higher education research within local contexts. This study concludes that a critical approach to teaching and learning research is needed to balance the local with the global in teaching and learning research in Colombia.
\end{abstract}

Keywords: SoTL; teaching and learning research; Colombia; higher education; investigación en el aula. 


\section{Introduction}

This paper presents the findings of a literature review that explored the incidence and nature of Scholarship of Teaching and Learning (SoTL) in higher education in Colombia. The study found evidence that while research of teaching and learning processes in Colombia is an increasing field of investigation, the knowledge emerging reflects its positioning as a nation that has been globalised ontologically and epistemologically and which draws extensively on the theories and practices developed in the 'global north' (de Sousa Santos, 2014; GuzmánValenzuela, 2017). The findings from this study reflect Colombia's position as a peripheral nation in a globalised world that has privileged knowledge production and ideas from certain countries while devaluing that from others (de Sousa Santos, 2014; Guzmán-Valenzuela, 2017). The SoTL literature emerging from Colombia reflects global dominant discourses of teaching and learning while revealing little of the contexts in which it has been produced.

Globalisation and its impact on education have been conceptualised in a variety of ways. The Critical Cultural Political Economy of Education (CCPEE) perspective is that education is shaped by different cultural, political and economic structures and that it should be understood within specific contexts (Robertson \& Dale, 2015). Education also acts to shape and reproduce these structures. An understanding of education from this viewpoint stimulates questions about the domination of certain knowledges and the subjugation of others.

This paper proposes that application of a CCPEE approach to learning and teaching research in Colombia would enhance its visibility and provide richer, more nuanced, and contextbased understandings of education processes. The questions and challenges that arise from the Colombian educational context could then be connected to those in other nations, providing opportunities for local ideas to go global rather than a global agenda imposing specific pedagogies in diverse contexts (de Sousa Santos, 20014). A critical approach to teaching and learning research would make visible 'other' kinds of educational globalisations and create new understandings of the world that embrace its diversity.

\section{Background}

The literature review shared in this paper is the first stage of a research project conducted by staff members from the Centre for Teaching and Learning at the Universidad de Los Andes (Uniandes) to develop strategies that support the university's focus on strengthening, integrating and coordinating its teaching and research-creation activities. Uniandes is a private university based in Bogotá, Colombia. Colombia is a pluriethnic and multicultural country with a majority 'mestizo' (mixed ethnicity) and minority indigenous (3.4\%) and afroColombian (10.6\%) populations (Dirección Ministerio de Educación, 2018). As a consequence of its diversity, education in Colombia takes place within rich cultural and linguistic settings that vary significantly between and within regions. A high level of 
inequality and a turbulent recent history of violence and corruption are also factors that influence the education landscape. A challenge for the Colombian higher education system is to contextualise teaching and learning within the current social, political and economic reality while forging a strong and competitive education system in a globalised world.

\section{Research Design}

A systematic literature review was conducted of teaching and learning research in higher education in Colombia. In this review learning and teaching research refers to research conducted by academics of their own pedagogical practice in the higher education sector in Colombia. Theoretical research was excluded from the review.

The literature search was conducted using the library search engines of Uniandes and Charles Darwin University (CDU), Australia, which provided access to 40 and 256 databases respectively. There was some overlap of major databases such as EBSCO, Wiley, ProQuest, Science Direct, Web of Science and SAGE, but the individual collections were significantly different and reflected each university's geo-political positioning. Searches of the two institutional collections enabled the identification of scholarly literature emerging from English and Spanish language sources in international and regional publications. The literature review also included articles identified in Google Scholar and from a scan of publications listed in the websites of Colombian universities known to have strong interest in pedagogy including Universidad Pedagógica Nacional, Universidad Nacional de Colombia, Universidad del Norte, Universidad de los Andes. This led to the identification of additional journal articles and edited books with a focus on SoTL.

Potential articles were selected from review of abstracts. The texts were then read in full to confirm their inclusion in the study and to identify key themes, methodologies and pedagogies. The search was not date restricted and the review identified literature published between 1999 and 2018. The search terms used were 'Colombia', 'Scholarship of Learning and Teaching', 'SoTL', 'classroom research' and 'higher education' in English, and ‘investigación en el aula’, innovación en el aula’, ‘innovación pedagógica’ and ‘educación superior' in Spanish. A limitation of the study is the narrow focus of these terms given the wide range of themes, disciplines and approaches in teaching and learning research. Specific methodologies such as action research were not included in the search. It is likely that an increase in the search terms and widening the scope to search more university websites and journals published by Colombian universities would reveal a higher incidence of SoTL in higher education in Colombia than reflected by the findings of this review. 


\section{Findings}

\subsection{Teaching and learning research is increasing in Colombia}

The review identified 83 journal articles and 103 book chapters focusing on teaching and learning research in higher education in Colombia published between 1999 and 2018. Of these articles eight were published between 1999 and 2006, 35 in the six years 2007 to 2012, and 40 articles in the six years 2013 to 2018. This provides far greater evidence of SoTL activity in Colombia than identified in a previous study by Guzmán-Valenzuela (2017), which identified only five SoTL articles from authors affiliated with Colombian universities between 2000 and 2015 in a search of the Web of Science database. Despite the difference in volume of articles identified in the two studies, both show that SoTL is an increasing field of study in higher education in Colombia, as in other Latin American countries.

\subsection{There is an unevenness in teaching and learning research in Colombia}

Teaching and learning research in Colombia is concentrated in the hands of less than a fifth of the nation's universities. Academic staff affiliated with 34 of Colombia's 189 universities (uniRank, 2019) were responsible for the production of the journal articles identified in this study. Of these 34 universities, staff from two universities produced 29 (33\%) of all journal articles: Uniandes produced 15 articles (17\%), while Universidad Nacional de Colombia (Universidad Nacional), a public university, produced 14 (16\%) of the articles. It is notable that these two universities are highly ranked in the 2019 QS World University Ranking (272 and 275 respectively) and are in the top ten universities in Latin America (QS, 2019). Staff affiliated with just 14 universities produced $77 \%$ of the total number of articles, while the remaining 20 universities produced just one article each. Of these articles, 47 (54\%) emerged from public universities and 40 (46\%) from private universities. Additionally, 103 book chapters were identified in books published by private universities of which 96 were in books published by Universidad del Norte (Uninorte) and seven in books published by Uniandes.

\subsection{Institutional support is linked to participation in teaching and learning research}

The universities, which produced the majority of the articles and chapters, related to SoTL, Uniandes, Uninorte and Universidad Nacional, have central offices that provide support for the integration of digital technologies into higher education teaching: the Centro para la Excelencia Docente (Uninorte), Conécta-Te (Uniandes) and inTIColombia (Universidad Nacional). Hence, the incorporation of learning technologies with teaching practice is a main theme emerging from Colombian learning and teaching research, with $41 \%$ of all SoTL research identified relating to technology integration. The extent and nature of the support provided by these centres is varied. At Uninorte, the support is systematic and focused on publication whereas at Uniandes and Universidad Nacional the support is more individually focused, with publication a positive by-product of support for technology integration. 


\subsection{Spanish and English are languages of publication in Colombia}

While English is the overwhelming language of publication of SoTL journal articles with 70 (84\%) of the articles reviewed published in English, in contrast 100\% of the book chapters identified were published in Spanish, Colombia's national language. The literature reflects the strength of Spanish as a language of research dissemination within Colombia along with English, which is regarded as the global language of academic discourse in many disciplines (Cortés \& Arellano, 2017). The high number of articles in English reflects the publication by Colombian universities of English language journals, such as Profile: Issues in Teachers' Professional Development published by the Universidad Nacional de Colombia and the Colombian Applied Linguistics Journal published by the Universidad Distrital Francisco José de Caldas. Other journals such as the International Journal of Bilingual Education and Bilingualism, published by Routledge, accept articles in English and in Spanish.

\subsection{SoTL is emerging from a range of disciplines}

SoTL in Colombia is emerging from a range of disciplines. There is a strong focus on English language teaching, with $69 \%$ of the articles relating to English teaching either as a specialised field or in the context of bilingual education or teacher education. The remaining literature is from a range of disciples. Science based disciplines such as medicine (Ankle et al., 2018), pharmacy (Valderrama Sanabria \& Castaño Riobueno, 2017), biological sciences (Archila et al., 2018) and engineering (Rosero-Zambrano et al., 2018) were represented in the literature. Other disciplines such as architecture (Navarro Morales \& Londoño, 2018), language education (McDougald, 2013; Pineda Hoyos, 2018), social sciences (Lobo, 2017) and business (Zambrano \& Guerrero, 2009) are also represented. The disciplines of physics (de Castro \& Martínez Gómez (Eds), 2017) and mathematics (Rojas Álvarez et al. (Eds), 2013) are strongly represented in disciplinary-focused edited books emanating from Uninorte.

\subsection{Research in teaching and learning reflects global themes and theories}

The literature reveals that the methodological approaches to research in the classroom, the theories that these are based on, and the pedagogical practices that are the objects of study reflect global themes and dominant approaches to investigation. Learning technologies were a major theme of research, reflected in $41 \%$ of the journal articles, and in the majority of the edited books published by Uninorte. The literature encompassing learning technologies included topics such as the use of flipped classrooms (Navarro Morales \& Londoño, 2018), active learning (Lobo, 2017), and problem based learning (Echavarria, 2010). Other pedagogical dilemmas such as teaching large groups of students are also evident in the literature (de Castro \& Martínez Gómez (Eds), 2017). There was little evidence in the literature of place-based theories of teaching or learning, or contextually based pedagogies or research practices. Exceptions included a focus on bilingualism, a focus of Colombia 
educational policy (Archila et al., 2018), and an article focusing on the learning of indigenous students written by an indigenous author (Cuasilpud Canchala, 2010).

\section{Discussion}

The literature reviewed in this study indicates that teaching and learning research in higher education in Colombia is increasing and is much stronger than suggested by previous research (Guzmán-Valenzuela, 2017). However, there is an "unevenness of SoTL activities” (De Courcy et al., 2017, p.1) across the higher education sector. The literature reviewed presents a view of teaching and learning research emerging strongly from the most respected public and private educational institutions.

The amount of teaching and learning research taking place in Colombia is clearly linked to the level of institutional support provided to staff members. At Uninorte, Uniandes and Universidad Nacional de Colombia this support is predominantly linked to engagement in technology integration in teaching practice, which is evident in almost half of the research literature reflecting technology related themes.

Although English is regarded as the primary language for dissemination of academic research in many disciplines (Cortés \& Arellano, 2017), this study found a significant amount of research from Colombia published in Spanish, particularly in book chapters. This suggests a push back to the status quo of English as ‘the' global language, and the positioning of Spanish as a legitimate language for academic discourse. Uninorte's publications, in particular, reflect a strategy to prioritise the dissemination of pedagogical innovation and research to the Spanish-speaking world despite the pressure faced by academics to publish in high status English language journals in order to enhance their international profile and career prospects.

The themes, theories, pedagogies and methodologies utilised across the literature were drawn primarily from western research orientations. This reflects a globalisation of education that privileges dominant global discourses of education over local knowledges. The literature reviewed "does not take into consideration the complexity and richness of teaching and learning in specific contexts” (Guzmán-Valenzuela, 2017, p.5). While global themes are important to education in Colombia, there is little to situate most of the teaching and learning research in the political, economic or social context in which it is taking place. This renders silent the specific and localised challenges that face higher education teaching in Colombia. One of the few exceptions found in the literature is the framing of bilingual scientific literacy in the context of Colombia's official language program, Colombia Bilingüe (Archila et al., 2018). Paradoxically, the focus on Spanish-English bilingualism in a country that is linguistically diverse reinforces the global dominance of English and highlights the marginalisation of knowledge production in other languages spoken in Colombia. 
The literature clearly indicates that measures are needed to promote and support research that makes visible the diverse contexts and localised challenges in the Colombian educational landscape. One measure is the use of critical approaches, such as CCPEE to interrogate the globalisation of teaching and learning research and to foreground localised knowledges, particularly those produced in "peripheral regions such as Latin America" (GuzmánValenzuela, 2017, p.5). A CCPEE approach can be used to focus attention on the cultural, political and economic structures that impact on education in different contexts, and to stimulate different types of questions about educational practice (Robertson \& Dale, 2015).

Robertson \& Dale (2015) propose four key educational 'moments' within a CCPEE approach that provide specific questions to draw out the context in which educational practices take place. These moments guide critical questioning about the nature and context of educational practice, the impact of educational politics and the nexus between politics and practice, the broad political context and social project of education (such as the relationship between education and neo-liberalism), and finally, the outcomes and consequences of the educational process. The purpose of these moments is to stimulate critical questioning about teaching practice from different angles that may not seem evident at first glance and to interrogate educational norms and their unwitting reproduction. In sum, a critical approach stimulates richer, more nuanced and context-based understandings of teaching and learning processes.

\section{Conclusion}

The literature review reported in this study set out to examine the extent and nature of teaching and learning research in Colombia. It identified a growing body of literature in teaching and learning research, with Spanish and English prevalent as languages of academic dissemination. The literature is being generated mainly by three universities with the common characteristic that each has an educational development centre with a focus on generating teaching innovation, research and publication. The educational challenges emerging from the literature reflect global themes and concerns with little that contextualise them within the social, political and economic contexts of Colombia. This study concludes with a vision for greater visibility of the local context in teaching and learning research through critical approaches that create new understandings of education in a globalised world.

\section{References}

Ankle, V., Peña-Silva, R.A., Valencia, D.M. \& Rincón-Perez, C.W. (2018). Validation of clay modelling as a learning tool for the periventricular structures of the human brain. Anatomical Sciences Education, 11(2), 137-145. 
Archila, P.A., Molina, J. \& Truscott de Mejía, A.M. (2018). Using bilingual argumentation to promote undergraduates' bilingual scientific literacy: Socrative as an immersive participation tool. International Journal of Bilingual Education and Bilingualism, 1-24.

Cortés, J.A. \& Arellano, I.D. (2017). The relevance of English in Colombian scientific research awareness. English Language Teaching, 10(5), 127-32.

Cuasilpud Canchala, R.E. (2010). Indigenous Students’ Attitudes towards Learning English through a Virtual Program: A Study in a Colombian Public University. Profile: Issues in Teachers' Professional Development, 12(2), 133-152.

de Castro, A. \& Martínez Gómez, A. (Eds). (2017). Transformar para Educar 2: Investigación en clases numerosas. Barranquilla: Universidad del Norte.

De Courcy, E., Loblaw, T., Paterson, J., Southam, T. \& Wilson, M.M. (2017). Framework for strengthening the scholarship of teaching and learning in the Canadian college sector. The Canadian Journal for the Scholarship of Learning and Teaching, 8(2), 1-20.

de Sousa Santos, B. (2014). Epistemologies of the south: Justice against epistemicide. New York and London: Routledge.

Dirección Ministerio de Educación. (2018). Grupos étnicos en Colombia. https://www.mineducacion.gov.co/1759/w3-article-378980.html

Echavarria, M.V. (2010). Problem-based learning application in engineering. Revista Escuela de Ingeniería de Antioquia, 14, 85-95.

Guzmán-Valenzuela, C. (2017). The geopolitics of research in teaching and learning in the university in Latin America. SOTL in the South, 1(1), 4-18.

Hylton, F., Tauss, A. \& Duque Agudelo. J.F. (2018). Remaking the Common Good: The Crisis of Public Higher Education in Colombia. NACLA Nov.16. Retrieved from https://nacla.org/news/2018/11/17/remaking-common-good-crisis-public-highereducation-colombia

Lobo, G.J. (2017). Active Learning Interventions and Student Perceptions. Journal of Applied Research in Higher Education, 9(3), 465-473.

McDougald, J.S. (2013). The use of new technologies among in-service Colombian ELT teachers. Colombian Applied Linguistics Journal. 15(2), 247-264.

Navarro Morales, M.E. \& Londoño, R. (2018). Inverted classroom teaching in the first-year design studio, a case study. British Journal of Educational Technology. Published online 8 September 2018. doi:10.1111/bjet.12711

Pineda Hoyos, J.E. (2018). Error correction and repair moves in synchronous learning activities. International Journal of Educational Technology in Higher Education. 15(23).

QS. (2019). Top Universities. Retrieved from https://www.qs.com/rankings/

Robertson, S. L., \& Dale, R. (2015). Towards a 'critical cultural political economy’ account of the globalising of education. Globalisation, Societies and Education, 13(1), 149-170.

Rodriguez Bernal, C.M. (2017). Student-centred strategies to integrate theoretical knowledge into project development within architectural technology lecture-based modules. Architectural Engineering and Design Management. 13(3), 223-242.

Rojas Álvarez, C.J., Escudero Trujillo, R. \& Cervantes Campo, G. (2013). Innovación en las clases de matemáticas: Experiencias Metodológicas. Barranquilla: Universidad del Norte. 
Rosero-Zambrano, C.A., Ávila, A., Osorio, L.A. \& Aguirre, S. (2018). Impact of Adding Internet Technology on student Performance and Perception of Autonomy in Fundamentals of Engineering course. Journal of Science Technology and Education. 27(2), 177-187.

uniRank. (2019). Top universities in Colombia. Retrieved from https://www.4icu.org/co/

Valderrama Sanabria, M.L. \& Castaño Riobueno, G.A. (2017). Solucionando dificultades en el aula: Una estrategia usando el aprendizaje basado en problemas. International Journal of Bilingual Education and Bilingualism, 8(3), 1907 - 1918.

Zambrano, W.R. \& Guerrero, D.E. (2009). Diseño pedagógico virtual de desarrollo empresarial con apoyo de las TIC. Revista UDCA Actualidad y Divulgación Científica, 12(1), 27-36. 